\title{
Statins as a Primary Prevention: Which One is Most Effective? A Systematic Review and Meta-Analysis \\ Gemma Figg $^{1}$, Alex Jervis ${ }^{1}$, Susannah Champion', Jane Langley ${ }^{2}$ and Gary Adams ${ }^{3 *}$
}

${ }^{1}$ MNurSci, Faculty of Medicine and Health Sciences, School of Health Sciences, The University of Nottingham, Nottingham, NG7 2RD, United Kingdom ${ }^{2} B S c$ (Hons), Intensive Care, United Lincolnshire ULH Trust, Greetwell Road, Lincoln, Lincolnshire, LN2 5QY, Andy Meal

${ }^{3}$ Faculty of Medicine and Health Sciences, The Insulin Diabetes Experimental Research Group, University of Nottingham, Nottingham, NG7 2UH, United Kingdom

\begin{abstract}
Background: Type 2 diabetics are at high risk of atherosclerosis and Cardiovascular (CV) events due to their associated dyslipidemic profile. Adverse levels of the lipid triad: Low-Density Lipoprotein Cholesterol (LDL-C), HighDensity Lipoprotein Cholesterol (HDL-C) and Triglycerides (TGs), have been shown to be major contributing factors. Statins (HMG-CoA reductase inhibitors) are recommended as first-line lipid therapy as evidence has shown their effectiveness in primary and secondary prevention of $\mathrm{CV}$ events. However, there is limited evidence specifically focused on primary prevention in Type 2 Diabetes Mellitus (T2DM) and dyslipidemia. The main purpose of this review was to assess the efficacy of statins in type 2 diabetics with dyslipidemia for the primary prevention of $\mathrm{CV}$ events.
\end{abstract}

Methods: A systematic review was carried out to determine the effectiveness of statins in T2DM and dyslipidemia. A comprehensive literature search identified Randomised Control Trials (RCTs) specific to participants with T2DM and dyslipidemia without prior CV events, which investigated the effects of statins on the lipid triad. Bias and quality of the studies were assessed and data extracted was critically analysed. Meta-analyses were carried out to determine the significance of statin effects. PRISMA guidelines were adhered to throughout.

Results: 10 RCTs were included investigating the effects of six statins. Statins were shown to improve the lipid triad by lowering LDL-C and TGs and increasing HDL-C, in agreement with previous research. Atorvastatin and rosuvastatin were shown to be most potent in reducing LDL-C and TGs and simvastatin showed the greatest increases in HDL-C. Meta-analyses demonstrated significance favouring statins for LDL-C and TG reductions but less evidence of significant effect of HDL-C improvement with all statins. Statins were well tolerated and adverse effects were minimal.

Conclusion: Primary prevention in this high risk population is very important. Statins are effective at reducing $\mathrm{CV}$ event risk, and clinicians should have knowledge of most appropriate statin treatments for patients based on individual lipid levels.

Keywords: Type 2 diabetes mellitus; Statins; Preventative medicine

\section{Introduction}

The metabolic pathway that produces cholesterol and other isoprenoids is known as the mevalonate pathway. The rate-controlling enzyme of this pathway is 3-hydroxy-3-methyl-glutaryl-CoA reductase or HMG-CoA reductase (HMGCR). This rate-controlling step in the biosynthesis of isoprenoids and sterols can be restricted by the use of statins [1].

This step involves the four-electron reductive deacylation of HMGCoA to CoA and mevalonate. It is catalyzed by HMGR in a reaction that proceeds as follows:

(S) $\mathrm{HMG} \mathrm{CoA}+2 \mathrm{NADPH}+2 \mathrm{H}^{+} \Rightarrow$ (R)

\section{Mevalonate $+2 \mathrm{NADP}^{+}+\mathrm{CoASH}$}

Where $\mathrm{NADP}^{+}$is the oxidized form of nicotinamide adenine dinucelotide, NADPH is the reduced form of $\mathrm{NADP}^{+}$, and $\mathrm{CoASH}$ is the reduced form of CoA.

One specific intervention for the use of HMG-CoA reductase inhibitors or statins is the potent effect on cholesterol [2]. The dyslipidemic profile of patients presenting with T2DM is distinguished by increased Triglycerides (TGs) and decreased High-Density Lipoprotein Cholesterol (HDL-C). Low-density lipoproteins (LDL) become smaller and denser causing atherogenicity, even if concentrations are not significantly increased [3]. Lipoprotein Lipase
(LPL), necessary for TG breakdown, is decreased due to insulin deficiency [4]. Decreased TG clearance, contributes to increase hepatic Very-Low-Density Lipoproteins (VLDL), which lower HDL-C by exchanging cholesterol from HDL to VLDL. HDL become smaller and cleared more easily, resulting in decreased HDL-C levels. HDL-C is cardio-protective and reduction is accompanied by reduced antioxidant and anti-atherogenic activities. HDL-C reduction also means LDL oxidation is not prevented as effectively. Small, dense LDL particles result from increased VLDL. They are pro-atherogenic and readily undergo oxidative modification [5]. Oxidised LDL is taken up by macrophages to form foam cells. Accumulation of foam cells form fatty streaks, invading arterial walls, proceeding to atherosclerosis and associated macrovascular effects [6].

The consequences of dyslipidemia in T2DM make apparent the

*Corresponding author: Gary Adams, PhD, Insulin Diabetes Experimental Research Group, Faculty of Medicine and Health Sciences, The University of Nottingham, Nottingham, NG7 2UH, United Kingdom, Tel: +44(0)115-8230901; Fax: +44(0)115-8230999; E-mail: Gary.Adams@nottingham.ac.uk

Received April 17, 2013; Accepted May 17, 2013; Published May 24, 2013

Citation: Figg G, Jervis A, Champion S, Langley J, Adams G (2013) Statins as a Primary Prevention: Which One is Most Effective? A Systematic Review and MetaAnalysis. J Cardiovasc Dis Diagn 1: 109. doi:10.4172/2329-9517.1000109

Copyright: (C) 2013 Figg G, et al. This is an open-access article distributed unde the terms of the Creative Commons Attribution License, which permits unrestricted use, distribution, and reproduction in any medium, provided the original author and source are credited. 
Citation: Figg G, Jervis A, Champion S, Langley J, Adams G (2013) Statins as a Primary Prevention: Which One is Most Effective? A Systematic Review and Meta-Analysis. J Cardiovasc Dis Diagn 1: 109. doi:10.4172/2329-9517.1000109

Page 2 of 7

need to deliver care to this high risk group in order to reduce premature mortality [7]. T2DM is considered 'a cardiovascular disease per se' and evidence suggests prevention should be sought as though CVD is present, even without signs of manifestation [8]. Studies have shown T2DM patients without CVD are just as at risk of CV events as those without DM with CVD.

First-line pharmacological intervention to improve lipids and prevent $\mathrm{CV}$ complications in $\mathrm{T} 2 \mathrm{DM}$ is thus the use of statins. LDL-C, HDL-C and TG levels are all high risk factors for cardiac events in diabetics with dyslipidemia, so aim of treatment is to improve all. High risk levels include: LDL-C $\geq 130 \mathrm{mg} / \mathrm{dL}$; HDL-C $\leq 40 \mathrm{mg} / \mathrm{dL}$; and TGs $>150 \mathrm{mg} / \mathrm{dL}[3,9]$.

Current statins available are: Atorvastatin, Fluvastatin, Pravastatin, Rosuvastatin and Simvastatin [10]. Statins reduce cholesterol synthesis and up-regulate LDL receptor synthesis, which promotes cholesterol removal from the blood [5]. Statins are well tolerated with generally mild side effects [11]. The potentially fatal side-effect is myositis, leading to rhabdomyolysis and progressing to renal failure.

Primary and secondary CVD prevention trials showed statins enabled significant $\mathrm{CV}$ event reduction. There was limited information on primary prevention in DM until results from diabetes subgroups of the Heart Protection Study and the Collaborative Atorvastatin Diabetes Study [12] (Table 1). Both reduced CV risk significantly.
However, T2DM participants recruited did not on average have dyslipidemic profiles typical of T2DM manifestation. Participants may not have been at such high risk as dyslipidemic T2DM patients, as lipid complications may not yet have risen sufficiently to cause CV damage. It is questionable whether their findings would have been so beneficial if participants had more adverse lipids.

LDL-C, HDL-C and TGs all contribute to atherogenesis in T2DM, so guidelines for lipid levels need to be targetted. The American Diabetes Association recommends target treatment goals for T2DM with statins include: LDL-C $<100 \mathrm{mg} / \mathrm{dL}$; HDL-C $>40 \mathrm{mg} / \mathrm{dL}$ (men) and $>50 \mathrm{mg} /$ $\mathrm{dL}$ (women); and TG levels $<150 \mathrm{mg} / \mathrm{dL}$ [9]. From in-depth research on primary preventative trials in T2DM, it was discovered there are few studies that focus solely on this lipid triad in T2DM and dyslipidemia.

This Review focuses on statins as a primary prevention method to determine which statin is most effective in improving LDL-C, HDL-C and TG levels. By using participants with high-risk lipid profiles this Review will determine, which statin is greatest at achieving ADA target levels and at what dosage the most beneficial statin should be administered.

\section{Methods}

A SR of randomized controlled trials (RCTs) was carried out. This SR centred specifically on T2DM. Participants were required to have

\begin{tabular}{|c|c|c|c|c|c|c|c|}
\hline $\begin{array}{l}\text { Study } \\
\text { No. }\end{array}$ & Source/Year & Study Title & Study Design & Study Participants & $\begin{array}{l}\text { Study } \\
\text { Intervention }\end{array}$ & Study Outcomes & Study Findings \\
\hline 1 & $\begin{array}{l}\text { Lam, Chu, Wei } \\
\text { et. al (2006) }\end{array}$ & $\begin{array}{l}\text { The effects of } \\
\text { different doses } \\
\text { of atorvastatin on } \\
\text { plasma endothelin-1 } \\
\text { levels in type } 2 \\
\text { diabetic patients with } \\
\text { dyslipidemia. }\end{array}$ & $\begin{array}{l}\text { Study was a } \\
\text { randomized, dose- } \\
\text { ranging, open-labelled, } \\
\text { parallel group clinical } \\
\text { trial which aimed to } \\
\text { investigate the effect } \\
\text { of atorvastatin } 10,20 \\
\text { and } 40 \mathrm{mg} \text {, on plasma } \\
\text { endothelin (ET-1) } \\
\text { and CRP (C-reactive } \\
\text { protein) levels in } 29 \\
\text { participants with T2DM } \\
\text { and dyslipidemia. }\end{array}$ & $\begin{array}{l}29 \text { T2DM men and women aged } \\
18 \text { to } 80 \text {, from outpatient clinics } \\
\text { in Kaohsiung Veterans General } \\
\text { Hospital, Taiwan. Women were } \\
\text { required to be postmenopausal, } \\
\text { surgically sterilized or using } \\
\text { birth control. Participants had to } \\
\text { have an HbA1c (glycosylated } \\
\text { hemoglobin) level of } \leq 10 \text {; LDL-C } \\
\geq 130 \mathrm{mg} / \mathrm{dl} \text {; and a fasting TG level } \\
\text { of }<400 \mathrm{mg} / \mathrm{dl} \text {. }\end{array}$ & $\begin{array}{l}\text { Participants were } \\
\text { randomized to } \\
\text { receive either } \\
\text { atorvastatin } \\
10 \mathrm{mg}(n=10), \\
20 \mathrm{mg}(n=10) \text { or } \\
40 \mathrm{mg}(n=9), \text { daily } \\
\text { for } 12 \text { weeks. }\end{array}$ & $\begin{array}{l}\text { Outcome } \\
\text { parameters } \\
\text { measured after } \\
\text { the } 12 \text { weeks } \\
\text { were: TC, TGs, } \\
\text { HDL-C, LDL-C, } \\
\text { CRP, CK } \\
\text { (creatine kinase), } \\
\text { ET-1, fasting } \\
\text { glucose, HbA1c, } \\
\text { systolic blood } \\
\text { pressure and } \\
\text { diastolic blood } \\
\text { pressure. }\end{array}$ & $\begin{array}{l}\text { Atorvastatin } \\
20 \mathrm{mg} \text { was } \\
\text { found to be the } \\
\text { most beneficial } \\
\text { dose in treating } \\
\text { dyslipidemia in } \\
\text { T2DM. }\end{array}$ \\
\hline 2 & $\begin{array}{l}\text { Lawerence, } \\
\text { Reid, Taylor et.al } \\
(2004)\end{array}$ & $\begin{array}{l}\text { The effect of high } \\
\text { dose atorvastatin } \\
\text { therapy on lipids } \\
\text { and lipoprotein } \\
\text { subfractions in } \\
\text { overweight patients } \\
\text { with type } 2 \text { diabetes. }\end{array}$ & $\begin{array}{l}\text { Study was a double- } \\
\text { blind, randomized, } \\
\text { placebo-controlled } \\
\text { design, which aimed to } \\
\text { investigate the effects } \\
\text { of } 80 \mathrm{mg} \text { atorvastatin } \\
\text { on LDL, VLDL and } \\
\text { HDL over a period of } 8 \\
\text { weeks. }\end{array}$ & $\begin{array}{l}40 \text { overweight men and women } \\
\text { with T2DM. They were aged } \\
45-80 \text {, had a BMI of }>27 \mathrm{~kg} / \mathrm{m}^{2} \text {; } \\
\text { a TC of }>5 \mathrm{mmol} / / \text {; not on lipid } \\
\text { lowering therapy; on diet alone/ } \\
\text { oral hypoglycaemic agents in } \\
\text { monotherapy or combination } \\
\text { therapy with metformin and } / \text { or } \\
\text { sulphonylurea; and } \mathrm{HbAc} 1<10 \% \text {. }\end{array}$ & $\begin{array}{l}\text { Participants were } \\
\text { randomized } \\
\text { to receive } \\
\text { atorvastatin } \\
80 \mathrm{mg} \text { daily } \\
(\mathrm{n}=20) \text { or } \\
\text { placebo daily } \\
(\mathrm{n}=20) \text { for } 8 \\
\text { weeks. }\end{array}$ & $\begin{array}{l}\text { Outcomes } \\
\text { included: TC, } \\
\text { TGs, HDL-C, } \\
\text { apoB, TC/HDL-C } \\
\text { ratio as well as } \\
\text { LDL subfractions, } \\
\text { VLDL subfractions } \\
\text { and HDL } \\
\text { subfractions. }\end{array}$ & $\begin{array}{l}\text { High dose } \\
\text { atorvastatin } \\
\text { ( } 80 \mathrm{mg}) \text { had } \\
\text { beneficial effects } \\
\text { on lipoprotein } \\
\text { subfractions, } \\
\text { enhancing anti- } \\
\text { atherogenic } \\
\text { effects in T2DM } \\
\text { and dyslipidemia. }\end{array}$ \\
\hline 3 & $\begin{array}{l}\text { The DALI } \\
\text { study group } \\
(2001)\end{array}$ & $\begin{array}{l}\text { The effect of } \\
\text { aggressive } \\
\text { versus standard } \\
\text { lipid lowering } \\
\text { by atorvastatin } \\
\text { on diabetic } \\
\text { dyslipidemia. }\end{array}$ & $\begin{array}{l}\text { A double-blind, } \\
\text { placebo-controlled, } \\
\text { randomized study was } \\
\text { designed to assess the } \\
\text { effect of atorvastation } \\
10 \& 80 \mathrm{mg} \text { on plasma } \\
\text { TG levels after } 30 \\
\text { weeks. }\end{array}$ & $\begin{array}{l}217 \text { T2DM male and female } \\
\text { participants from outpatient clinics } \\
\text { in The Netherlands. Participants } \\
\text { were aged } 45-75 \text {; had a duration } \\
\text { of T2DM for at least a year; HbA1c } \\
\leq 10 \% \text {; fasting TC level between } \\
4.0 \text { and } 8.0 \mathrm{mmol} / / \text {; and fasting TG } \\
\text { level between } 1.5 \text { and } 6.0 \mathrm{mmol} / \mathrm{l} \text {. }\end{array}$ & $\begin{array}{l}\text { Participants were } \\
\text { randomized to } \\
\text { treatment with } \\
\text { either } 10 \mathrm{mg} \\
\text { atorvastatin } \\
(\mathrm{n}=73), 80 \mathrm{mg} \\
\text { atorvastatin } \\
(\mathrm{n}=72) \text { or } \\
\text { placebo ( } \mathrm{n}=72) \\
\text { for } 30 \text { weeks. } \\
\text { Participants } \\
\text { randomized to } \\
80 \mathrm{mg} \text { started } \\
\text { with } 40 \mathrm{mg} \text { for } 4 \\
\text { weeks then this } \\
\text { was increased to } \\
80 \mathrm{mg} \text {. }\end{array}$ & $\begin{array}{l}\text { Outcomes } \\
\text { measured after } 30 \\
\text { weeks treatment } \\
\text { included: TGs; } \\
\text { TC; LDL-C; } \\
\text { HDL-C; TC/ } \\
\text { HDL-C ratio; } \\
\text { FFA; apoB; LDL } \\
\text { particle size and } \\
\text { lipoprotein lipase. }\end{array}$ & $\begin{array}{l}\text { High dose } \\
\text { atorvastatin } \\
(80 \mathrm{mg}) \text { improved } \\
\text { the cholesterol- } \\
\text { related levels } \\
\text { of participants } \\
\text { with T2DM and } \\
\text { dyslipidemia, } \\
\text { more successfully } \\
\text { than lower dosage } \\
(10 \mathrm{mg}) \text {. }\end{array}$ \\
\hline
\end{tabular}

Table 1: Studies investigating the effects of atorvastatin treatment. 
Citation: Figg G, Jervis A, Champion S, Langley J, Adams G (2013) Statins as a Primary Prevention: Which One is Most Effective? A Systematic Review and Meta-Analysis. J Cardiovasc Dis Diagn 1: 109. doi:10.4172/2329-9517.1000109

Page 3 of 7

or have an aspect of a dyslipidemic profile as defined by LDL-C $\geq$ $130 \mathrm{mg} / \mathrm{dL}$; HDL-C $<40 \mathrm{mg} / \mathrm{dL}$ and TG levels $>150 \mathrm{mg} / \mathrm{dL}$. The focus was primary prevention of $\mathrm{CV}$ events so only participants without macrovascular conditions were included. All ages, sex and ethnicities were included to ensure findings were globally relevant to healthcare. Dose and duration of treatment was not specified. A comprehensive database search was carried out to identify eligible RCTs from the years 2000 to 2012.

Primary outcomes were LDL-C, HDL-C and TG levels after statin treatment and whether ADA targets were achieved. Secondary outcomes included adverse effects of statin treatments. This was important as statins may be effective at improving lipids but have side effects disadvantageous in administration.

The Cochrane Collaboration's tool for assessing risk of bias and the Critical Appraisal Skills Programme (CASP) tool were used to critically judge the sources. Using the CASP tool, each study was scored on a scale of 1-9, determining overall quality (low-high) [13].

Meta-analyses were carried out to provide precise estimates of overall treatment effects [14]. The $\mathrm{I}^{2}$ test assessed heterogeneity, which showed the percentage of variability in effect estimates due to heterogeneity rather than chance.

\section{Results}

The comprehensive search produced 601 potentially relevant RCTs. 568 were immediately excluded and 33 full texts were obtained. On detailed evaluation 10 studies remained for inclusion: 1) 3 investigated atorvastatin;2) 3 investigated simvastatin;3) 1 investigated rosuvastatin; and 4) 3 compared more than one statin, collectively consisting of: rosuvastatin, atorvastatin, fluvastatin, simvastatin, pravastatin and lovastatin.

\section{Primary outcome: Lipid triad levels}

All doses of atorvastatin investigated enabled significant percentage reductions in LDL-C and TGs. Atorvastatin $80 \mathrm{mg}$ showed greatest effect sizes for LDL-C $[15,16]$ (Figure 1) $\left(\mathrm{I}^{2}=97 \%\right)$ and $10 \mathrm{mg}$ demonstrated most significant TG decreases [15,17] (Figure 2) $\left(\mathrm{I}^{2}=97 \%\right)$. These represented some of the largest LDL-C and TG reductions compared to other statins.

In contrast, atorvastatin had less benefit on HDL-C. HDL-C was not improved by any atorvastatin dose investigated by Lam et al. [18] or Lawrence et al. [16] but was increased by $5-6 \%(\mathrm{p}<0.005)$ by $10 \mathrm{mg}$ and $80 \mathrm{mg}$ investigated by The DALI study group and by $7.4 \%$ with 10 mg investigated by Gentile et al. [15-18]. Meta-analyses demonstrated $10 \mathrm{mg}$ did cause significant effects (Figure 3$)\left(\mathrm{I}^{2}=97 \%\right)$. However, there was no strong evidence of significant effect of atorvastatin $80 \mathrm{mg}$ on HDL-C (Figure 4) $\left(\mathrm{I}^{2}=32 \%\right)$.

Studies investigating simvastatin showed improvement in the whole lipid triad, but demonstrated greatest improvements in HDL-C compared to other statins. Sheu et al. [19] showed $20 \mathrm{mg}$ enabled the largest HDL-C increase (table 2) (Figure 5). Simvastatin 80mg was the

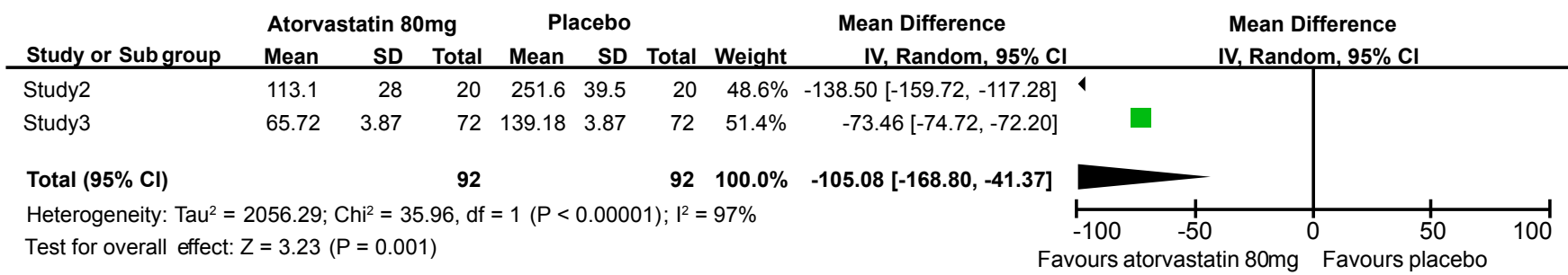

Figure 1: Forest plot of comparison: Atorvastatin $80 \mathrm{mg}$ vs Placebo: LDL-C.

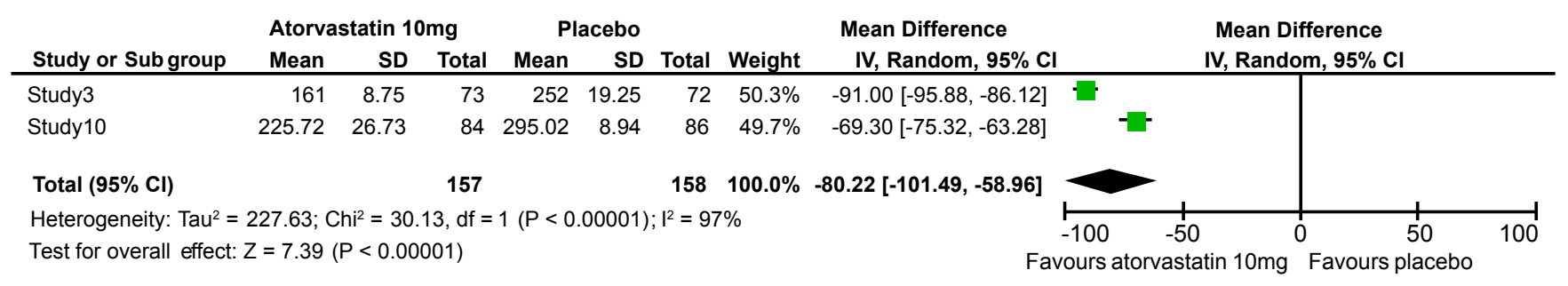

Figure 2: Forest plot of comparison: Atorvastatin 10mg vs Placebo: TGs.

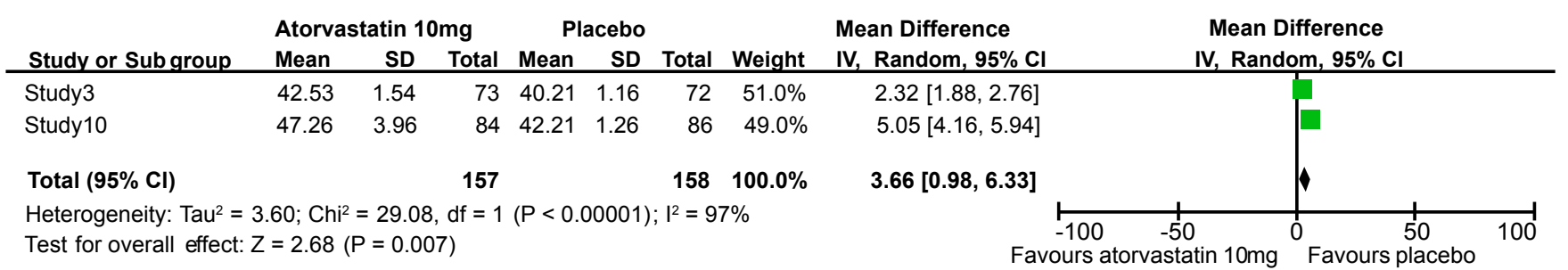

Figure 3: Forest plot of comparison: Atorvastatin 10mg vs Placebo: HDL-C. 
Citation: Figg G, Jervis A, Champion S, Langley J, Adams G (2013) Statins as a Primary Prevention: Which One is Most Effective? A Systematic Review and Meta-Analysis. J Cardiovasc Dis Diagn 1: 109. doi:10.4172/2329-9517.1000109

Page 4 of 7

dose found to cause most significant reductions in LDL-C and TGs from the simvastatin studies $(\mathrm{p}<0.01)[15,19]$.

Rosuvastatin was found to have similar reductions in LDL-C and TGs to atorvastatin (Table 3). Both Vergès et al. [20] and Betteridge and Gibson [21] demonstrated $20 \mathrm{mg}$ produced the greatest LDL-C and TG benefits $(-51 \% /-57.4 \%,-38 \% /-22.7 \%$, respectively) [20,21]. However, rosuvastatin was not effective at improving HDL-C.

Bevilacqua et al. found fluvastatin XL-80mg and simvastatin $20 \mathrm{mg}$ produced significant reductions in LDL-C and TGs $(\mathrm{p}<0.01)$ [22]. In contrast fluvastatin increased HDL-C significantly $(\mathrm{p}<0.05)$ whereas simvastatin did not modify HDL-C. Gentile and colleagues demonstrated atorvastatin showed greater benefits compared to simvastatin, pravastatin and lovastatin (Table 4) [17].

\section{Primary outcome: ADA targets achieved?}

The studies investigating atorvastatin showed variation in meeting
ADA targets. However, LDL-C, TGs and HDL-C targets were met by the majority of doses studied. There were differences between simvastatin studies in achieving LDL-C targets. However, all doses investigated achieved HDL-C target and no dose reached TG target.

It was not possible to determine whether rosuvastatin $20 \mathrm{mg}$ investigated by Vergès et al. enabled targets due to insufficient published data, however Betteridge and Gibson showed both rosuvastatin $10 \mathrm{mg}$ and $20 \mathrm{mg}$ were successful [20,21]. Bevilacqua et al. [22] demonstrated fluvastatin enabled LDL-C and HDL-C targets but not TGs. Gentile et al. showed no statin investigated achieved LDL-C or TG targets, but all met HDL-C target [17].

\section{Secondary outcome: Adverse effects}

Studies investigating atorvastatin presented most adverse effects, although numbers of participants affected were minimal. Simvastatin treatment was reported as well tolerated. Vergès et al. stated rosuvastatin

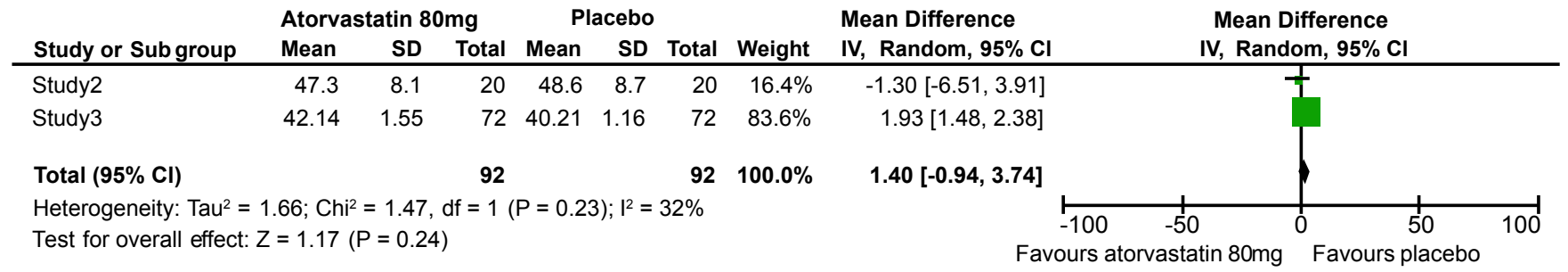

Figure 4: Forest plot of comparison: Atorvastatin $80 \mathrm{mg}$ vs Placebo: HDL-C.

\begin{tabular}{|c|c|c|c|c|c|c|c|}
\hline $\begin{array}{l}\text { Study } \\
\text { No. }\end{array}$ & Source/Year & Study Title & Study Design & Study Participants & Study Intervention & Study Outcomes & Study Findings \\
\hline 4 & $\begin{array}{l}\text { Heljić, Velija- } \\
\text { Ašimi and Kulić } \\
(2009)\end{array}$ & $\begin{array}{l}\text { The statins in } \\
\text { prevention of coronary } \\
\text { heart disease in type } \\
2 \text { diabetics. }\end{array}$ & $\begin{array}{l}\text { Randomized } \\
\text { control study to } \\
\text { investigate whether } \\
\text { statins reduced the } \\
\text { incidence of CHD } \\
\text { in type } 2 \text { diabetic } \\
\text { participants who } \\
\text { had no pre-existing } \\
\text { CHD. }\end{array}$ & $\begin{array}{l}95 \text { male and female } \\
\text { obese T2DM participants } \\
\text { without pre-existing } \\
\text { coronary heart disease. } \\
\text { Mean age was } 60.09 \text { and } \\
\text { mean BMI was } 31.59 \mathrm{~kg} / \\
\mathrm{m}^{2} \text {. Participants had } \\
\text { T2DM for a duration of } \\
\text { more than ten years. }\end{array}$ & $\begin{array}{l}\text { Participants were randomized } \\
\text { to either } 40 \text { mg simvastatin } \\
(n=45) \text { or placebo }(n=50) \\
\text { daily for } 6 \text { months. }\end{array}$ & $\begin{array}{l}\text { The study } \\
\text { measured } \\
\text { basal c-peptide; } \\
\text { HbA1c; CRP; } \\
\text { TC, TGs; HDL-C } \\
\text { and LDL-C, after } \\
\text { treatment of } 6 \\
\text { months, and also } \\
\text { after } 1 \text { year. }\end{array}$ & $\begin{array}{l}\text { Simvastatin } \\
\text { treatment reduced } \\
\text { the risk of CHD } \\
\text { in participants } \\
\text { with T2DM and } \\
\text { dyslipidemia, } \\
\text { without prior CHD. }\end{array}$ \\
\hline 5 & $\begin{array}{l}\text { Isley, Miles, } \\
\text { Patterson et al. } \\
(2006)\end{array}$ & $\begin{array}{l}\text { The effect of high- } \\
\text { dose simvastatin } \\
\text { on triglyceride- } \\
\text { rich lipoprotein } \\
\text { metabolism in patients } \\
\text { with type } 2 \text { diabetes } \\
\text { mellitus. }\end{array}$ & $\begin{array}{l}\text { Study was a } \\
\text { randomized, single- } \\
\text { blind, cross-over } \\
\text { design and aimed } \\
\text { to compare placebo } \\
\text { and high-dose } \\
\text { simvastatin (80mg } \\
\text { daily) on triglyceride- } \\
\text { rich lipoprotein TG } \\
\text { (TRL-TG) production } \\
\text { and clearance. }\end{array}$ & $\begin{array}{l}12 \text { obese male and } \\
\text { female participants } \\
\text { with T2DM and fasting } \\
\text { hypertriglyceridemia were } \\
\text { recruited as well as } 6 \\
\text { non-diabetic controls with } \\
\text { BMls of }<30 \mathrm{~kg} / \mathrm{m}^{2} \text {. }\end{array}$ & $\begin{array}{l}\text { The diabetic subjects } \\
\text { received either simvastatin } \\
80 \mathrm{mg} \text { daily or placebo for two } \\
12 \text { week periods. Subjects } \\
\text { who received placebo for } \\
\text { the first period then had } \\
\text { simvastatin } 80 \mathrm{mg} \text { for the } \\
\text { second period, and vice } \\
\text { versa. }\end{array}$ & $\begin{array}{l}\text { Outcomes } \\
\text { measured } \\
\text { included: LDL-C; } \\
\text { VLDL-C; TGs; } \\
\text { HDL-C; TRL-TG } \\
\text { secretion; TRL- } \\
\text { TG clearance; } \\
\text { and LPL activity. }\end{array}$ & $\begin{array}{l}\text { Simvastatin } \\
\text { increased TRL-TG } \\
\text { clearance, and } \\
\text { increased LPL } \\
\text { activity, resulting } \\
\text { in delipidation of } \\
\text { TRL in T2DM and } \\
\text { dyslipidemia. }\end{array}$ \\
\hline 6 & $\begin{array}{l}\text { Sheu, Jeng, } \\
\text { Lee et.al (2001) }\end{array}$ & $\begin{array}{l}\text { Simvastatin treatment } \\
\text { on postprandial } \\
\text { hypertriglyceride-mia } \\
\text { in type } 2 \text { diabetes } \\
\text { mellitus patients } \\
\text { with combined } \\
\text { hyperlipidemia. }\end{array}$ & $\begin{array}{l}\text { This RCT was } \\
\text { a double-blind, } \\
\text { placebo-controlled } \\
\text { study that was } \\
\text { initiated to compare } \\
\text { the effects of } \\
\text { simvastatin and } \\
\text { placebo on lowering } \\
\text { daily postprandial } \\
\text { TG. }\end{array}$ & $\begin{array}{l} \\
41 \text { male and female } \\
\text { T2DM subjects with LDL- } \\
\text { C>130mg/dL; fasting TG } \\
\text { level } 200-600 \mathrm{mg} / \mathrm{dL} \text {; not } \\
\text { receiving lipid lowering } \\
\text { drugs but had been on } \\
\text { lipid lowering diet } 6 \text { weeks } \\
\text { previously; and stable } \\
\text { glycaemic control with } \\
\text { oral hypoglycaemic drugs } \\
\text { for at least } 3 \text { months prior } \\
\text { to study. }\end{array}$ & $\begin{array}{l}\text { After } 6 \text { weeks of a lipid- } \\
\text { lowering diet, participants } \\
\text { were randomized to receive } \\
\text { either simvastatin } 20 \mathrm{mg} \\
(\mathrm{n}=24) \text { or placebo }(\mathrm{n}=14) \\
\text { once daily (at bedtime) for } \\
12 \text { weeks. The doses were } \\
\text { doubled after } 4 \text { weeks if } \\
\text { participants' LDL-C had not } \\
\text { exceeded } 130 \mathrm{mg} / \mathrm{dL} \text {. } 24 \\
\text { subjects }(15 \text { in simvastatin } \\
\text { group and } 9 \text { in placebo } \\
\text { group) also undertook a } \\
\text { mixed meal tolerance test, } \\
\text { which was performed at } \\
\text { baseline and at the end of } \\
\text { treatment. }\end{array}$ & $\begin{array}{l}\text { Outcomes } \\
\text { included } \\
\text { measurements } \\
\text { of: TC; HDL-C; } \\
\text { LDL-C; TC/ } \\
\text { HDL-C; as well } \\
\text { as fasting and } \\
\text { postprandial TG } \\
\text { concentrations. }\end{array}$ & $\begin{array}{l}\text { Simvastatin } \\
\text { improved the lipid } \\
\text { profile of its T2DM } \\
\text { participants as } \\
\text { well as reducing } \\
\text { postprandial TG } \\
\text { concentrations. }\end{array}$ \\
\hline
\end{tabular}

Table 2: Studies investigating the effects of simvastatin treatment. 


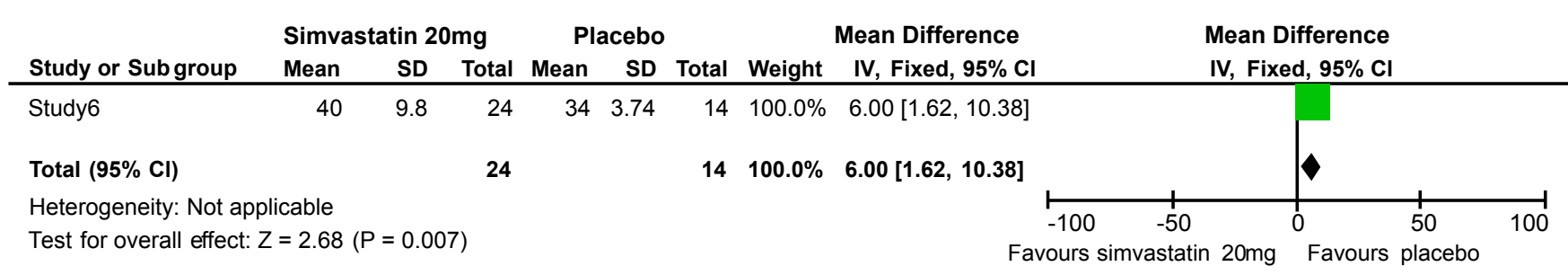

Figure 5: Forest plot of comparison: Simvastatin 20mg vs Placebo: HDL-C.

\begin{tabular}{|c|c|c|c|c|c|c|c|}
\hline Study No. & Source/Year & Study Title & Study Design & Study Participants & Study Intervention & Study Outcomes & Study Findings \\
\hline 7 & $\begin{array}{l}\text { Vergès, } \\
\text { Florentin, Baillot- } \\
\text { Rudoni et.al } \\
(2008)\end{array}$ & $\begin{array}{l}\text { Effects of } 20 \mathrm{mg} \\
\text { rosuvastatin on } \\
\text { VLDL1-, VLDL2-, } \\
\text { IDL- \& LDL-ApoB } \\
\text { kinetics in type } 2 \\
\text { diabetics. }\end{array}$ & $\begin{array}{l}\text { A randomized, double- } \\
\text { blinded, placebo- } \\
\text { controlled, cross-over } \\
\text { trial was carried out } \\
\text { to determine the } \\
\text { effects of rosuvastatin } \\
\text { versus placebo on the } \\
\text { metabolism of TG-rich } \\
\text { lipoproteins. }\end{array}$ & $\begin{array}{l}8 \text { participants were recruited } \\
\text { who had T2DM and diabetic } \\
\text { dyslipidemia characterised } \\
\text { by } \mathrm{TG}>1.70 \mathrm{mmol} / \mathrm{l} \text {; and HDL } \\
<1.03 \mathrm{mmol} / \mathrm{l} \text { in men and } \\
<1.29 \mathrm{mmol} / \mathrm{l} \text { in women. They } \\
\text { had been treated with oral } \\
\text { glucose lowering agents for at } \\
\text { least } 6 \text { months and had stable } \\
\text { HbA1c over this time. }\end{array}$ & $\begin{array}{l}\text { Participants undertook } \\
\text { a } 4 \text { week placebo } \\
\text { maintenance period and } \\
\text { were then randomized to } \\
\text { either rosuvastatin } 20 \mathrm{mg} \\
\text { or placebo once daily for } \\
6 \text { weeks. There was then } \\
\text { a crossover for a further } \\
6 \text { week treatment period. }\end{array}$ & $\begin{array}{l}\text { Outcomes } \\
\text { consisted of } \\
\text { glucose and lipid } \\
\text { parameters and } \\
\text { ApoB-100 kinetic } \\
\text { parameters. }\end{array}$ & $\begin{array}{l}\text { Rosuvastatin had } \\
\text { benficial effects on } \\
\text { the catabolism of } \\
\text { TG-rich lipoproteins, } \\
\text { aiding prevention } \\
\text { of atherosclerosis } \\
\text { in T2DM and } \\
\text { dyslipidemia. }\end{array}$ \\
\hline
\end{tabular}

Table 3: Studies investigating the effects of rosuvastatin treatment.

was well tolerated but Betteridge and Gibson demonstrated rosuvastatin caused serious adverse effects similar to atorvastatin [20,21]. Gentile et al. stated side effects for all statins studied were mild [17].

\section{Discussion}

This SR and meta-analysis showed support for statin administration to prevent $\mathrm{CV}$ events as they improved the lipid triad and aided achievement of ADA targets. However, issues were raised that contribute to knowledge of statin efficacy in T2DM.

Lam et al. found neither atorvastatin 10/20/40 mg improved HDL-C. In fact, HDL-C decreased with all doses and Lam et al. stated this was "not a negative dose-response effect of atorvastatin on HDL-C as previously reported [18].

Negative dose-response describes progressively decreasing HDL-C levels as dosage increases [12]. Wierzbicki and Mikhailidis found low dose atorvastatin increased HDL-C and ApoA-1, its associated apolipoprotein, but effects diminished with increasing dose suggesting negative dose-response [23]. However, these findings were not based on T2DM. They also found $10 \mathrm{mg}$ still increased HDL-C, however, another study showed $10 \mathrm{mg}$ decreased HDL-C, which suggests this latter study and researchers were correct in their statement $[18,23]$.

Similarly, Lawrence et al. found HDL-C decreased with atorvastatin $80 \mathrm{mg}$ [16]. They found significant negative effect on ApoA-1 and HDL-C $(\mathrm{p}<0.05)$ demonstrating high-dose atorvastatin potentially limits anti-atherogenic protection HDL-C provides. However, in contrast The DALI study group showed significant increases in HDL-C for both doses of atorvastation $(10 / 80 \mathrm{mg})(\mathrm{p}<0.005)$ [15]. The increase in HDL-C reduced the total cholesterol (TC): HDL-C ratio, which prevents against atherosclerosis.

Heljić et al. study demonstrated 6 months of simvastatin $40 \mathrm{mg}$ did not improve lipids as effectively as $80 \mathrm{mg}$ or $20 \mathrm{mg}[19,24,25]$. Evidence has shown $40 \mathrm{mg}$ can have greater effects in less time than shown by Heljić's study. In hypercholesterolaemic participants Miller, Dobs, Yuan et al. found $40 \mathrm{mg}$ improved lipids more significantly after six weeks and $\mathrm{Li}$ and colleagues demonstrated the same in two weeks $[26,27]$. Therefore the results from Heljićs study were potentially an anomaly.
It could be stated the results were due to obese participants. Increase in central adiposity decreases LPL activity and results in increased production of atherogenic particles [3]. Isley et al. [25] also used obese participants, but they were consuming a low-fat, low-cholesterol diet which may explain their improvement in LPL activity and therefore the lipid triad [23]. This could provide explanation for the differing results found by Heljić's study, whose participants were not diet-controlled.

Sheu et al. study showed the highest HDL-C increase (11\%) with simvastatin $20 \mathrm{mg}$, despite being the lowest simvastatin dose and the shortest simvastatin study [19]. However, Sheu stated treatment dose was doubled after 4 weeks if participants' LDL-C exceeded $130 \mathrm{mg} / \mathrm{dL}$. Without individual participant data, it was not determined how many participants this involved. The results of Sheu may have represented the effects of simvastatin $40 \mathrm{mg}$ as opposed to $20 \mathrm{mg}$.

Vergès et al. study found rosuvastatin $20 \mathrm{mg}$ did not improve HDL-C and gave no explanation why [20]. However, they found treatment significantly increased total catabolism of VLDL. This showed, although rosuvastatin $20 \mathrm{mg}$ did not increase HDL-C, it prevented HDL-C becoming TG-enriched and from becoming cleared more easily. Therefore rosuvastatin $20 \mathrm{mg}$ had indirect effects, suggesting if statins can prevent HDL-C decreasing, this is beneficial even if levels are not increased. Betteridge and Gibson [21] also found rosuvastatin was not significant at increasing HDL-C. However, they did not discuss VLDL catabolism so it cannot be certain rosuvastatin consistently shows the same benefits [26].

Bevilacqua et al. demonstrated fluvastatin XL-80mg increased HDL-C but simvastatin $20 \mathrm{mg}$ did not [22]. This contrasted to the simvastatin studies that demonstrated its effects on the whole lipid triad. However, despite dissimilar HDL-C findings between fluvastatin and simvastatin, improvements in ApoA-1 were similar $(+8 \mathrm{mg} /$ $\mathrm{dL},+13 \mathrm{mg} / \mathrm{dL}$, respectively). Therefore lack of HDL-C increase with simvastatin $20 \mathrm{mg}$ was possibly a discrepancy.

The duration of studies had an impact on achieving ADA targets. The studies by Lam and Lawrence showed atorvastatin $10 \mathrm{mg} / 80$ mg did not achieve LDL-C targets, however, The DALI study group found they did, which was the longest study of the three. Similarly Isley [25] and Betteridge and Gibson [21] found simvastatin $80 \mathrm{mg}$ 
Citation: Figg G, Jervis A, Champion S, Langley J, Adams G (2013) Statins as a Primary Prevention: Which One is Most Effective? A Systematic Review and Meta-Analysis. J Cardiovasc Dis Diagn 1: 109. doi:10.4172/2329-9517.1000109

Page 6 of 7

\begin{tabular}{|c|c|c|c|c|c|c|c|}
\hline $\begin{array}{l}\text { Study } \\
\text { No. }\end{array}$ & Source/Year & Study Title & Study Design & Study Participants & Study Intervention & Study Outcomes & Study Findings \\
\hline 8 & $\begin{array}{l}\text { Betteridge and } \\
\text { Gibson (2007) }\end{array}$ & $\begin{array}{l}\text { Effects of rosuvastatin on } \\
\text { lipids, lipoproteins and } \\
\text { apolipoproteins in the } \\
\text { dyslipidemia of diabetes. }\end{array}$ & $\begin{array}{l}\text { A double-blind, } \\
\text { randomized, } \\
\text { multicentre study } \\
\text { was carried out to } \\
\text { compare the effects } \\
\text { of rosuvastatin and } \\
\text { atorvastatin on LDL-C } \\
\text { as well as other } \\
\text { secondary lipid and } \\
\text { lipoprotein endpoints. }\end{array}$ & $\begin{array}{l}494 \text { participants were } \\
\text { recruited from } 45 \text { centres } \\
\text { in the UK. They were } \\
\text { male and female; had } \\
\text { a diagnosis of T2DM; } \\
\text { at least age } 18 ; \text { were } \\
\text { treated with diet and/ } \\
\text { or oral glucose-lowering } \\
\text { agents; had at least two } \\
\text { fasting blood glucose } \\
\text { levels of }>7.0 \mathrm{mmol} / / \\
\text { before randomization; } \\
\text { and a plasma TG level of } \\
\leq 6.0 \mathrm{mmol} / \mathrm{l} \text {. }\end{array}$ & $\begin{array}{l}494 \text { participants } \\
\text { were randomized } \\
\text { to treatment with } \\
\text { rosuvastatin } 10 \mathrm{mg} \\
(\mathrm{n}=248) \text { or atorvastatin } \\
10 \mathrm{mg}(\mathrm{n}=246) \text { once } \\
\text { daily. Treatment with } \\
10 \mathrm{mg} \text { was carried out } \\
\text { for } 8 \text { weeks, and this } \\
\text { was then doubled to } \\
20 \mathrm{mg} \text { for a further } 8 \\
\text { weeks. }\end{array}$ & $\begin{array}{l}\text { Outcomes } \\
\text { measured } \\
\text { included HDL-C } \\
\text { subfractions; } \\
\text { TGs; ApoA } \\
\text { subfractions; TC/ } \\
\text { HDL-C; LDL-C/ } \\
\text { HDL-C; non- } \\
\text { HDL-C/HDL-C; } \\
\text { ApoB/ApoA; } \\
\text { LDL-C; and TC, } \\
\text { after both } 8 \text { weeks } \\
\text { and } 16 \text { weeks of } \\
\text { treatment. }\end{array}$ & $\begin{array}{l}\text { Rosuvastatin was } \\
\text { shown to improve } \\
\text { subfractions more } \\
\text { beneficially than } \\
\text { equal doses of } \\
\text { atorvastatin. }\end{array}$ \\
\hline 9 & $\begin{array}{l}\text { Bevilacqua, } \\
\text { Righini, Barrella } \\
\text { et.al (2005) }\end{array}$ & $\begin{array}{l}\text { Effects of fluvastatin } \\
\text { slow-release (XL-80mg) } \\
\text { versus simvastatin } \\
\text { (20mg) on the lipid triad } \\
\text { in patients with type } 2 \\
\text { diabetes. }\end{array}$ & $\begin{array}{l}\text { This RCT was a } \\
\text { prospective, open- } \\
\text { label, blinded- } \\
\text { endpoint study that } \\
\text { was conducted in } \\
\text { a single centre in } \\
\text { Italy. It was carried } \\
\text { out to determine } \\
\text { whether statins have } \\
\text { positive effects on all } \\
\text { components of the } \\
\text { lipid triad in type } 2 \\
\text { diabetics. }\end{array}$ & $\begin{array}{l}94 \text { participants were } \\
\text { included with T2DM } \\
\text { and the lipid triad (TGs } \\
>2.3 \mathrm{mmol} / / \text {; HDL- } \\
\mathrm{C}<1.3 \mathrm{mmol} / / \text {; and } \\
\text { elevated levels of small } \\
\text { dense LDL. All participants } \\
\text { were being treated with } \\
\text { metformin, glimepiridie, } \\
\text { and glibenclamide, and } \\
\text { some were also receiving } \\
\text { insulin glargine. }\end{array}$ & $\begin{array}{l}\text { After a } 4 \text { week } \\
\text { dietary run-in phase, } \\
\text { participants were } \\
\text { randomized to receive } \\
\text { either fluvastatin } \\
\text { XL-80mg }(n=48) \text { or } \\
\text { simvastatin }(n=46) \\
\text { once daily (at bedtime) } \\
\text { for } 8 \text { weeks. }\end{array}$ & $\begin{array}{l}\text { Outcomes } \\
\text { focused on were } \\
\text { the lipid triad } \\
\text { of LDL-C, TGs } \\
\text { and HDL-C, as } \\
\text { well as ApoA-1; } \\
\text { ApoB and LDL } \\
\text { subfractions. }\end{array}$ & $\begin{array}{l}\text { The lipid triad was } \\
\text { more successfully } \\
\text { controlled with } \\
\text { fluvastatin XL- } \\
80 \mathrm{mg} \text {, compared } \\
\text { to simvastatin, } \\
\text { in participants } \\
\text { with T2DM and } \\
\text { dyslipidemia. }\end{array}$ \\
\hline 10 & $\begin{array}{l}\text { Gentile, Turco, } \\
\text { Guarino et.al } \\
(2000)\end{array}$ & $\begin{array}{l}\text { Comparative efficacy } \\
\text { study of atorvastatin } \\
\text { vs simvastatin, } \\
\text { pravastatin, lovastatin } \\
\text { and placebo in type } 2 \\
\text { diabetic patients with } \\
\text { hypercholesterolae-mia. }\end{array}$ & $\begin{array}{l}\text { A multi-centre, open- } \\
\text { label, randomized, } \\
\text { parallel- group, } \\
\text { comparative study } \\
\text { in order to compare } \\
\text { atorvastatin 10mg } \\
\text { daily with simvastatin } \\
10 \mathrm{mg} \text { daily, lovastatin } \\
20 \mathrm{mg} \text { daily, } \\
\text { pravastatin 20mg daily } \\
\text { and placebo. Focus } \\
\text { of the study was to } \\
\text { compare the efficacy } \\
\text { and safety of the } \\
\text { statins. }\end{array}$ & $\begin{array}{l}\text { 409 male and female } \\
\text { T2DM participants were } \\
\text { studied. They were aged } \\
50-65 \text { and had all had the } \\
\text { onset of diabetes after } \\
\text { the age of } 40 \text {. They had } \\
\text { LDL-C concentrations } \\
\text { of }>160 \mathrm{mg} / \mathrm{dL} \text { and TG } \\
\text { concentrations of } \leq 400 \mathrm{mg} / \\
\text { dL. }\end{array}$ & $\begin{array}{l}\text { Participants began } \\
\text { by following the NIH } \\
\text { modified NCEP step } \\
1 \text { diet programme } \\
\text { for } 6 \text { weeks before } \\
\text { being randomized to } \\
\text { atorvastatin }(n=84) \text {, } \\
\text { simvastatin }(n=78) \text {, } \\
\text { pravastatin }(n=81) \text {, } \\
\text { lovastatin }(n=80) \text { or } \\
\text { placebo ( } n=86) \text { for } 24 \\
\text { weeks. The diet was also } \\
\text { continued throughout the } \\
\text { duration of the treatment. }\end{array}$ & $\begin{array}{l}\text { Outcomes } \\
\text { measured were } \\
\text { the percentage } \\
\text { changes in } \\
\text { LDL-C levels } \\
\text { after } 24 \\
\text { weeks and the } \\
\text { percentage } \\
\text { change in TC, } \\
\text { TG and HDL-C at } \\
\text { week } 24 . \\
\end{array}$ & $\begin{array}{l}\text { Atorvastatin } \\
\text { showed the } \\
\text { greatest } \\
\text { percentage } \\
\text { changes in } \\
\text { all outcomes } \\
\text { measured, } \\
\text { compared to } \\
\text { other statins } \\
\text { and placebo } \\
\text { investigated. }\end{array}$ \\
\hline
\end{tabular}

Table 4: Studies investigating the comparative effects of statins

and atorvastatin $10 \mathrm{mg}$, respectively, were near to TG target, but had treatment been longer target may have been met. Baseline lipid levels also had an impact. Very high baseline TGs were demonstrated by The DALI study group and Bevilacqua [22], which could have affected how quickly TG levels were reduced.

ADA targets for HDL-C differ for men and women $(>40 \mathrm{mg} / \mathrm{dL}$, $>50 \mathrm{mg} / \mathrm{dL}$ ), respectively. The RCTs consisted of male and female participants but individual participant data was unavailable. The target value of $>40 \mathrm{mg} / \mathrm{dL}$ was used to represent the mixed sex samples. HDL-C targets were met by atorvastatin $10 \mathrm{mg} / 80 \mathrm{mg}$ however it must be emphasized baseline HDL-C for these groups were higher than final measurements, so atorvastatin did not enable target achievement $[19,20]$. These shows T2DM patients with lower HDL-C would not necessarily benefit from atorvastatin to increase HDL-C.

One participant withdrew from Lawrence study because of increases in Alanine Transaminase (ALT). ALT is a liver enzyme and elevations indicate liver dysfunction. Ballantyne et al. found hypercholesterolemic participants treated with atorvastatin $80 \mathrm{mg}$ were more likely to have ALT elevations [28]. Neither Lam study nor The DALI study group reported this with lower doses of atorvastatin so elevation could be related to higher dosage. This is supported by Armitage who stated effect of statins on transaminase is dependent upon dose [29]. Betteridge and Gibson [21] stated incidence of myalgia was low for both atorvastatin and rosuvastation, but consistent with other clinical trials [30]. However, if a consistent finding, this may present safety risks of taking either.

Only a small number of RCTs were available to examine for this SR. More studies would have been sufficient to confirm or disagree with the findings. Two studies used Taiwanese participants so their results cannot be generalised globally due to cultural differences in lifestyle and genetics. Three studies used overweight participants so also cannot be generalizable to all with T2DM. However, obesity is a contributing factor to T2DM development and due to increasing obesity levels findings are applicable to overweight patients. The studies varied in lengths of T2DM diagnosis. If participants had T2DM a long time, baselines were possibly less adverse than if recently diagnosed due to treatments commenced. The studies varied in durations and number of participants. This heterogeneity influenced the findings and potentially impacted upon how successful statins appeared.

\section{Implications and recommendations for clinical practice}

The results from this Review imply T2DM patients should have lipid levels measured early. It is important treatment is not standardized with simvastatin $40 \mathrm{mg}$, as recommended, because patients' levels may vary. How long patients go undiagnosed, due to lack of symptoms, can 
Citation: Figg G, Jervis A, Champion S, Langley J, Adams G (2013) Statins as a Primary Prevention: Which One is Most Effective? A Systematic Review and Meta-Analysis. J Cardiovasc Dis Diagn 1: 109. doi:10.4172/2329-9517.1000109

Page 7 of 7

affect how high risk levels may be. By knowing patients' levels, statin treatment can be individualised.

For those with high LDL-C and TGs, atorvastatin or rosuvastatin may be beneficial as a primary preventative treatment. Levels are likely to reduce quickly due to their potent effects. High doses may be most effective, but caution should be taken in case of adverse effects. In contrast, those with less high risk profiles may benefit from simvastatin. Simvastatin showed overall benefit with all doses, but $80 \mathrm{mg}$ may present more significant effects in this population.

Care of T2DM dyslipidemic patients should be individualised. It is important to determine whether treatment is improving patients' lipids. Monitoring lipid triads and reviewing statin treatment regularly would assist in CVD prevention.

\section{Conclusion}

T2DM patients can have very adverse lipid profiles. Baseline lipids of participants in studies systematically reviewed emphasised the importance of primary prevention. As well as simvastatin, as recommended by NICE, this SR has shown the efficacy of atorvastatin and rosuvastatin. Atorvastatin and rosuvastatin were most potent in reducing LDL-C and TGs, whereas simvastatin showed the greatest increases in HDL-C. Meta-analyses demonstrated significance favouring statins for LDL-C and TG reductions, but showed less evidence of significant effect for HDL-C improvements. The ten studies showed overall statins were well tolerated and adverse effects were minimal.

Future research may consider studies all of the same intervention duration, in order to reduce heterogeneity. Research may be warranted on whether atorvastatin and rosuvastatin improve HDL-C in T2DM and dyslipidemia, and whether negative dose-responses associated with atorvastatin, and increases in ApoA-I with rosuvastatin are consistent findings. High-dosage fluvastatin showed significant benefits in this review, but further research in this population would be needed to conclude whether it could be a CV prevention measure.

\section{References}

1. Corsini A, Maggi FM, Catapano AL (1995) Pharmacology of competitive inhibitors of HMG-CoA reductase. Pharmacol Res 31: 9-27.

2. Fisher M (2003) Heart disease and diabetes, London: Martin Dunitz Ltd.

3. Haffner S (2003) Management of Dyslipidemia in Adults with Diabetes. Diabetes Care 26: 83-86.

4. Johnstone MT, Veves A (2005) Diabetes and cardiovascular disease. New Jersey: Humana Press Inc.

5. Beckman JA, Creager MA, Libby $P$ (2002) Diabetes and atherosclerosis: epidemiology, pathophysiology, and management. JAMA 287: 2570-2581.

6. Rang HP, Dale MM, Ritter JM and Flower RJ Pharmacology (2007) Philadelphia: Churchill Livingstone.

7. Burgert TS (2006) Glucose and insulin metabolism in obese youth. Pediatr Endocrinol Rev 3 Suppl 4: 555-559.

8. Cuny T, Guerci B, Cariou B (2012) New avenues for the pharmacological management of type 2 diabetes: an update. Ann Endocrinol (Paris) 73: 459468

9. (ADA), A.D.A. Standards of medical care in diabetes The American Diabetes Association (ADA) (2011) Standards of medical care in diabetes 2011 [Online]. Available at:

10. De Loecker I, Preiser JC (2012) Statins in the critically ill. Ann Intensive Care 2: 19.

11. Graversen L, Christensen B, Borch-Johnsen K, Lauritzen T, Sandbaek A (2011) Lipid-lowering drugs as primary prevention in general practice: do patients reach guideline goals and continue treatment? ADDITION Denmark Scand J Prim Health Care 29: 216-221.

12. Mikhailidis DP, Wierzbicki AS (2000) HDL-cholesterol and the treatment of coronary heart disease: contrasting effects of atorvastatin and simvastatin. Curr Med Res Opin 16: 139-146.

13. Higgins JPT, Altman DG, Assessing risk of bias in included studies. 2010: Cochrane Organisation.

14. Whitehead A, Meta-analysis of controlled clinical trials. 2002, Chichester: John Wiley \& Sons Ltd.

15. Diabetes Atorvastin Lipid Intervention (DALI) Study Group (2001) The effect of aggressive versus standard lipid lowering by atorvastatin on diabetic dyslipidemia: the DALI study: a double-blind, randomized, placebo-controlled trial in patients with type 2 diabetes and diabetic dyslipidemia. Diabetes Care 24: $1335-1341$.

16. Lawrence JM, Reid J, Taylor GJ, Stirling C, Reckless JP (2004) The effect of high dose atorvastatin therapy on lipids and lipoprotein subfractions in overweight patients with type 2 diabetes. Atherosclerosis 174: 141-149.

17. Gentile S, Turco S, Guarino G, Sasso CF, Amodio M et al. (2000) Comparative efficacy study of atorvastatin vs. simvastatin, pravastatin, lovastatin and placebo in type 2 diabetic patients with hypercholesterolaemia. Diabetes Obesity and Metabolism. 2: 355-362.

18. Lam HC, Chu CH, Wei MC, Keng HM, Lu CC, et al. (2006) The effects of different doses of atorvastatin on plasma endothelin-1 levels in type 2 diabetic patients with dyslipidemia. Exp Biol Med (Maywood) 231: 1010-1015.

19. Sheu WH, Jeng CY, Lee WJ, Lin SY, Pei D, et al. (2001) Simvastatin treatment on postprandial hypertriglyceridemia in type 2 diabetes mellitus patients with combined hyperlipidemia. Metabolism 50: 355-359

20. Vergès B, Florentin E, Baillot-Rudoni S, Monier S, Petit JM, et al. (2008) Effects of $20 \mathrm{mg}$ rosuvastatin on VLDL1-, VLDL2-, IDL- and LDL-ApoB kinetics in type 2 diabetes. Diabetologia 51: 1382-1390.

21. Betteridge DJ, Gibson JM (2007) Effects of rosuvastatin on lipids, lipoproteins and apolipoproteins in the dyslipidaemia of diabetes. Diabet Med 24: 541-549.

22. Bevilacqua M, Righini V, Barrella M, Vago T, Chebat E, et al. (2005) Effects of fluvastatin slow-release (XL $80 \mathrm{mg})$ versus simvastatin $(20 \mathrm{mg})$ on the lipid triad in patients with type 2 diabetes. Adv Ther 22: 527-542.

23. Anthony S Wierzbicki, Dimitri P Mikhailidis (2002) Dose-response effects of atorvastatin and simvastatin on high-density lipoprotein cholestero in hypercholesterolaemic patients: a review of five comparative studies. International Journal of Cardiology 84: 53-57.

24. Heljic B, Velija-Asimi Z, Kulic M (2009) The statins in prevention of coronary heart diseases in type 2 diabetics. Bosn J Basic Med Sci 9: 71-76.

25. Isley WL, Miles JM, Patterson BW, Harris WS (2006) The effect of high-dose simvastatin on triglyceride-rich lipoprotein metabolism in patients with type 2 diabetes mellitus. J Lipid Res 47: 193-200.

26. Miller M, Dobs A, Yuan Z, Battisti WP, Borisute H, et al. (2004) Effectiveness of simvastatin therapy in raising HDL-C in patients with type 2 diabetes and low HDL-C. Curr Med Res Opin 20: 1087-1094.

27. Li JJ, Chen MZ, Chen X, Fang CH (2003) Rapid effects of simvastatin on lipid profile and C-reactive protein in patients with hypercholesterolemia. Clin Cardiol 26: 472-476.

28. Ballantyne CM, Blazing MA, Hunninghake DB, Davidson MH, Yuan Z, et al. (2003) Effect on high-density lipoprotein cholesterol of maximum dose simvastatin and atorvastatin in patients with hypercholesterolemia: Results of the Comparative HDL Efficacy and Safety Study (CHESS). American Heart Journal 146: 862-869.

29. Armitage $\mathrm{J}$ (2007) The safety of statins in clinical practice. Lancet 370: 1781 1790.

30. Betteridge DJ (2011) Lipid control in patients with diabetes mellitus. Nat Rev Cardiol 8: 278-290 